九州大学学術情報リポジトリ

Kyushu University Institutional Repository

\title{
INDEX TO CONTRIBUTION SERIES 3, ENTOMOLOGICAL LABORATORY, FACULTY OF AGRICULTURE, KYUSHU UNIVERSITY
}

Hirashima, Yoshihiro

https://doi.org/10.5109/2518

出版情報: ESAKIA. 28, pp.125-150，1989-03-03. Entomological Laboratory，Faculty of Agriculture, Kyushu University

バージョン：

権利関係 : 


\title{
INDEX TO CONTRIBUTION SERIES 3, ENTOMOLOGICAL LABORATORY, FACULTY OF AGRICULTURE, KYUSHU UNIVERSITY
}

\author{
Compiled by \\ YoshiHIRo HIRASHIMA \\ Entomological Laboratory, Faculty of Agriculture, \\ Kyushu University, Fukuoka 812, Japan
}

Contribution Series 3, Entomological Laboratory, Faculty of Agriculture, Kyushu University started in 1972 when I was appointed Professor of Entomology and took over the chairmanship of that laboratory. From that time, more than 300 papers (about 30 now in press) will have been published until the end of March, 1989 as listed below. I am proud that we were able to publish so many interesting papers to contribute to entomological knowledge during the last 17 years of my professorship.

I thank Dr. 0. Tadauchi, Dr. K. Ogata and Mr. Y. Abe for their assistance in preparation of the manuscript of this Index.

3-001. 平䳋義宏 (HIRASHIMA，Yoshihiro） 1972. 孤独性蜂類の巣中における蛹の定位に関する研究. [Comparative studies on the orientation of pupae in the nests of solitary bees and wasps (Hymenoptera：Aculeata)] 九大農学芸誌, 26:27-45. (In Japanese with English summary)

3-002, 槙原寛 . 竹野功一 . 中條道崇 (MAKIHARA, Hiroshi, TAKENO, Kôichi and CHÔ JÔ, Michitaka) 1972. 英彦山におけるツキヨタケより得られた昆虫類 I. [Check list of the insects collected from Lampteromyces japonicus (Kawam.) Sing. on Mt. Hiko] 九大農学芸誌, 26：595600. (In Japanese with English summary)

3-003. KANMIYA, Kenkichi 1972. New record of a spider predator of the genus Pseudogaurax Malloch, 1915, from Japan, with a note on a European species Gaurax venustus Czerny (Diptera : Chloropidae). Mushi, $\mathbf{4 6}:$ 39-43.

3-004. TAKETANI, Akihiko and YASUMATSU, Keizô 1973. Descriptions and some biological notes of two new species of the genus Periclistus Förster from Japan (Hymenoptera, Cynipidae). Esakia, (8) : 1-11.

3-005. OKUMA, Chiyoko and WONGSIRI, Tanongchit 1973. Second report on the spider-fauna of the paddy fields in Thailand. Mushi, $47: 1-17$.

3-006。鈴木芳人・高木正見・山中正博 (SUZUKI, Yoshito, TAKAGI, Masami and YAMANAKA, Masahiro） 1974. 演場所を利用したマーキング法によるアゲハの移動の研究. [Studieson the dispersal of Papilio xuthus L. (Lepidoptera, Papilionidae) by mark-and-recapture method at their 
nocturnal roosting sites] 昆蟲, 42:79-86. (In Japanese with English summary)

3-007. HIRASHIMA, Yoshihiro and MAETA, Yasuo 1974. Bees of the genus Megachile sensulato (Hymenoptera, Megachilidae) of Hokkaido and Tohoku district of Japan. Kontya, 42 : 157173.

3-008. HIRASHIMA, Yoshihiro 1974. Annotated check list of the Japanese species of the genus Megachile sensu lato (Hymenoptera, Megachilidae), with description of a new species. Kontyâ, 42: 174-180.

3-009. HIRASHIMA, Yoshihiro and HANEDA, Yoshito 1973. New or little known species of the genus Andrena from Japan (Hymenoptera, Andrenidae). Mushi, 47: 67-73.

3-010. HIRASHIMA, Yoshihiro 1973. Two new species of the genus Osmia from Japan and N. China (Hymenoptera, Megachilidae). J.Fac.Agr., Kyushu U niv., 18 : 63-68.

3-011. HAYASHI, Masami 1974. The cicadas of the genus Platypleura (Homoptera, Cicadidae) in the Ryukyu Archipelago, with the description of a new species. Kontya, 42: 232-253.

3-012. HIRASHIMA, Yoshihiro and KIFUNE, Teiji 1974. A new species of Strepsiptera parasitic on an Orthopteron from Okinawa, Japan (Myrmecolacidae) (Studies on the Japanese Strepsiptera II). Mushi, $47:$ 75-79.

3-013. HAYASHI, Masami 1974. A revision of the tribe Cicadini in the Ryukyu Archipelago (Homoptera : Cicadidae). Mushi, 47 : 155-166.

3-014. YOSHIYASU, Yutaka 1975. New records of some Oriental species of the subfamily Pyraustinae from Japan (Lepidoptera : Pyralidae). Tyô to Ga, 26: 1-7.

3-015. WONGSIRI, Tanongchit, NAVAVICHIT, Suchada, NILPANIT, Pinit, YANO, Kôji and YASUMATSU, Keizô 1974. Remarks on two noteworthy dipterous predators of the larvae of stalk borers including Chilo polychrysus (Meyrick) in S. E. Asia. Mushi, 4'7: 111-117.

3-016. 大熊千代子 (OKUMA，Chiyoko) 1974.ト3ップ・ネットによって捕獲された水田の飛行グモ. [Aeronautic spiders caught by the trap net above paddy fields] 九大農学芸誌, 29:79-85. (In Japanese with English summary)

3-017. 平鴆義宏・矢野宏二・中條道崇 (HIRASHIMA, Yoshihiro, YANO, Kôji and CHOJÔ, Michitaka) 1974.ミヤマキリシマの害虫類, 特に九重と霧島におけるクジュウフユシャクとキシタエダシャク の発生について. [Insect pests of Rhododendron kiusianum Makino (Ericaceae), with special reference to outbreaks of Inurois sp. and Arichannamelanaria Linnaeus (Lepidoptera, Geometridae) on Mts. Kuja and Kirishima] 九大農学芸誌, 29:87-115, 3 pls. (In Japanese with English summary)

3-018. TADAUCHI, Osamu 1975. Numerical phenetic relationships of the genus Andrena (Hymenoptera, Andrenidae) of Japan, with a new introduction of component pattern diagrams. Kontyâ, 43 : 181-201.

3-019. HAYASHI, Masami 1975. On the species of the genus Meimuna Distant (Homoptera, Cicadidae) of the Ryukyus. I. Synonymy and description of the species. Kontyâ, 43: 281-298.

3-020. YANO, Kôji, MIURA, Tadashi, NOHARA, Keigo, WONGSIRI, Tanongchit, RESMA, Paulino and LEE, Lawrence H. Y. 1975. Preliminary evaluation on the use of a modified Malaise trap in paddy fields. Mushi, $48:$ 125-144. 
3-021. KIFUNE, Teiji and HIRASHIMA, Yoshihiro 1975. A new species of the genus Elenchus from Thailand (Strepsiptera : Elenchidae) (Notulae Strepsipterologicae-II). Mushi, 48:145-148, 2 pls.

3-022. HAYASHI, Masami 1975. On the species of the genus Meimuna Distant (Homoptera, Cicadidae) of the Ryukyus. II. Geographic and individual variations and mode of coexistence. Kontyâ, 43 : 412-421.

3-023. HIRASHIMA, Yoshihiro and TADAUCHI, Osamu 1975. A new subgenus of the genus Andrena (Hymenoptera, Andrenidae) from Japan and allied areas. J.Fac. Agr., Kyushu Univ., $19: 175-186$.

3-024. HAYASHI, Masami 1976. On the species of the genus Mogannia Amyot et Serville, 1843 (Homoptera, Cicadidae), of the Ryukyus and Taiwan. Kontyâ, $44: 27-42$.

3-025. HAYASHI, Masami 1976. Description of the nymphs of Moganniaminuta Matsumura

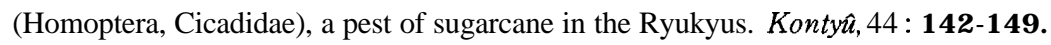

3-026. YOSHIYASU, Yutaka 1975. Systematic study of the subfamily Pyraustinae of Japan (Lepidoptera : Pyralidae). 1. Descriptions of a new species and 2 unrecorded species. J. Fac. Agr., Kyushu Univ., 19 : 187-195.

3-027. HIRASHIMA, Yoshihiro 1975. New species of the bees of the genus Palaeorhiza Perkins from New Guinea mainly in the collection of the Rijksmuseum van Natuurlijke Historie, Leiden (Hymenoptera, Colletidae). J. Fac. Agr., Kyushu Univ., 20 : 27-46.

3-028. HIRASHIMA, Yoshihiro 1975. Revision of the bee genus Xenorhiza Michener of New Guinea, with descriptions of two new species (Hymenoptera, Colletidae). Esakia, (9) : 1-14.

3-029. HIRASHIMA, Yoshihiro and YAMAGISHI, Kenzou 1975. Embolemidae of Japan, with description of a new species of Embolemus from Hachijo Island (Hymenoptera, Bethyloidea). Esakia, (9) : 25-30.

3-030. MAKIHARA, Hiroshi 1977. A new species of the genus Sybra from Japan (Coleoptera : Cerambycidae). Ent. Rev. Japan, $30: 25-29,1$ pl.

3-031a. HAYASHI, Masami 1978. The Cicadidae (Homoptera, Auchenorrhyncha) from East and Central Nepal (Part I). Bull. Nat. Sci. Mus., Ser. A (Zool.), 4: 163-195.

3-031b. HAYASHI, Masami 1978. The Cicadidae (Homoptera, Auchenorrhyncha) from East and Central Nepal (Part II). Bull. Nat. Sci. Mus., Ser. A (Zool.), $4:$ 267-279.

3-032. NAKAO, Shun-ichi, ASAHINA, Syoziro, MIURA, Tadashi, WONGSIRI, Tanongchit, PANGGA, Guillermo A., LEE, Lawrence H. Y. and YANO, Kôji 1976. The paddy field Odonata collected in Thailand, the Philippines and Hong Kong. Kurume Univ. J., 25 : 145-159.

3-033. 大熊千代子 (OKUMA, Chiyoko) 1977. 福岡市津屋の水田地帯に生息する3モ類の発生消長に関 する研究. [Studies on the seasonal fluctuation of the spiders in the paddy field ecosystem at Tsuya, Fukuoka City] 九大農学芸誌, 31:133-144. (In Japanese with English summary)

3-034. HIRASHIMA, Yoshihiro 1977. Revision of the Japanese species of Nesoprosopis, with descriptions of two new species (Hymenoptera, Colletidae, Hylaeus). Esakia, (10) : 21-43.

3-035. MAKIHARA, Hiroshi 1977. Cerambycidae of Kuroshima Island, with descriptions of two new 
species and two new subspecies (Coleoptera). Esakia, (10) : 45-69.

3-036. MAKIHARA, Hiroshi 1976. Description of a new species of Anoplophora from Ogasawara Islands (Coleoptera : Cerambycidae). Bull.Jap. Ent. Acad., 10 : 9-12.

3-037. HAYASHI, Masami 1977. A new species of the genus Tibicen Latreille (Homoptera, Cicadidae) from Taiwan. Kontyû, $45: 185-191$.

3-038. OKUMA, Chiyoko 1977. A new species of the genus Tetragnathu (Araneae : Tetragnathidae) from the Ryukyus, Japan. Acta Arachnol., 27 : 27-32.

3-039. TADAUCHI, Osamu 1978. A comparison of various clustering methods applied to the Japanese Andrenid bees. Zool. Mag., 87 : 117-124.

3-040. TADAUCHI, Osamu 1978. The effect of using different numbers of characters on the clustering method as applied to Japanese Andrenid bees. Zool. Mag., 87 : 186-190.

3-041. YANO, Kôji 1978. Fauna1 and biological studies on the insects of paddy fields in Asia. Part I. Introduction and Sciomyzidae from Asia (Diptera). Esakia, (11) : 1-27.

3-042. YONEDA, Yutaka 1978. A new species of the genus Ascogaster Wesmael (Hymenoptera, Braconidae) from Japan. Kontyâ, $46: 291-296$.

3-043. VUNGSILABUTR, Preecha 1978. Biological and morphological studies of Paracentrobia andoi (Ishii) (Hymenoptera : Trichogrammatidae), a parasite of the green rice leafhopper, Nephotettix cincticeps Uhler (Homoptera : Deltocephalidae). Esakia, (11) : 29-51.

3-044. HIRASHIMA, Yoshihiro and KIFUNE, Teiji 1978. Strepsipterous parasites of Homoptera injurious to the rice plant in Sarawak, Borneo, with description of a new species (Notulae Strepsipterologicae-III). Esakia, (11) : 53-58.

3-045. HIRASHIMA, Yoshihiro and KIFUNE, Teiji 1978. A new species of the genus Halictophagus from Iriomote Island, Okinawa, Japan (Strepsiptera : Halictophagidae) (Studies on the Japanese Strepsiptera IV). Esakia, (11) : 59-61.

3-046. OKUMA, Chiyoko, LEE, Moon Hong and HOKYO, Nobuhiko 1978. Fauna of spiders in a paddy field in Suweon, Korea. Esakia, (11): 81-88.

3-047. HIRASHIMA, Yoshihiro 1978. A synopsis of the bee genus Palaeorhiza Perkins (Hymenoptera, Colletidae) of New Guinea. Part I. Subgenus Palaeorhiza s. str. Esakia, (11) : 89-119.

3-048. YAMAMOTO, Masaru 1979. A new species of the genus Chironomus (Diptera, Chironomidae) from Japan. Kontyñ $47: 8-17$.

3-049. MORIMOTO, Katsura 1978. On the genera of Oriental Cryptorhynchinae (Coleoptera : Curculionidae). Esakia, (11): 121-143.

3-050. 大熊千代子.千国安之輔 (OKUMA, Chiyoko and CHIKUNI, Yasunosuke) 1978. 長野県産アシ ナガグモの 1 新種. [A new species of the genus Tetragnatha (Araneae : Tetragnathidae) from Nagano Pref., Japan] Acta Arachnol., 28:I-7. (In Japanese with English summary)

3-051. 上田恭一郎 (UEDA, Kyoichiro) 1978. コウモリガの雄交尾器の形態とその名称の変遷. [The male genital structure of some Hepialid moths with a historical review of their terminology] 蝶と蛾, 29: 191-206. (In Japanese with English summary)

3-052. MORIMOTO, Katsura 1978. The family Anthribidae of Japan (Coleoptera). Part 1. Esakia, 
(12) : $17-47$.

3-053. MAKIHARA, Hiroshi 1978. New longicom-beetles of the Ryukyus and Taiwan (Coleoptera : Cerambycidae). Esakia, (12) : 49-62.

3-054. HIRASHIMA, Yoshihiro 1978. A synopsis of the bee genus Palaeorhiza Perkins (Hymenoptera, Colletidae) of New Guinea. Part II. Subgenera Gressittapis, Noonadania, Sphecogaster, Anchirhiza, Ceratorhiza.Esakia, (12) : 63-87.

3-055. HIRASHIMA, Yoshihiro 1978. Some Asian species of Austronomia, a subgenus of Nomia, with descriptions of three new species from Sri Lanka (Hymenoptera, Halictidae). Esakia, (12) : 89-101.

3-056. MORIMOTO, Katsura 1978. Check-list of the family Rhynchophoridae (Coleoptera) of Japan, with descriptions of a new genus and five new species. Esakia, (12): 103-118.

3-057. HIRASHIMA, Yoshihiro, AIZAWA, Keio, MIURA, Tadashi and WONGSIRI, Tanongchit 1979. Field studies on the biological control of leafhoppers and planthoppers (Hemiptera : Homoptera) injurious to rice plants in South-East Asia. Progress report for the year 1977. Esakia, (13) : I-20, 1 pl.

3-058. MIURA, Tadashi, HIRASHIMA, Yoshihiro and WONGSIRI, Tanongchit 1979. Egg and nymphal parasites of rice leafhoppers and planthoppers. A result of field studies in Thailand in 1977. Esakia, (13): 21-44.

3-059. 森本桂 (MORIMOTO, Katsura) 1979. 新渴県のゾウムシ類目録. [Curculionid-beetles of Niigata Prefecture, Japan] 越佐昆会報, (50)：25-47. (In Japanese with English summary)

3-060. MORIMOTO, Katsura 1979. The family Anthribidae of Japan (Coleoptera). Part 2. Esakia, (14) : : 1-23.

3-061. MORIMOTO, Katsura 1979. Descriptions of two new species of the family Brentidae from Japan (Coleoptera). Esakia, (14) : 25-30.

3-062. MIYAMOTO, Syôiti and MAKIHARA, Hiroshi 1979. A new species of the genus Neopanorpa Weele from the Nansei Islands (Mecoptera). Esakia, (14) : 57-60.

3-063. KIFUNE, Teiji and HIRASHIMA, Yoshihiro 1979. Two new species of Strepsiptera from Thailand (Notulae Strepsipterologicae-V). Esakia, (14) : 61-71.

3-064. OKUMA, Chiyoko 1979. A new species of the genus Tetragnatha (Araneae: Tetragnathidae) from tropical Asia. Esakiu, (14) : 73-77.

3-065. MIYAZAKI, Minoru and HIRASHIMA, Yoshihiro 1979. The genus Trimorus Forster of Japan (Hymenoptera, Scelionidae). Esakia, (14) : 79-92.

3-066. YASUMATSU, Keizô and KAMIJO, Kazuaki 1979. Chalcidoid parasites of Dryocosmus kuriphilus Yasumatsu (Cynipidae) in Japan, with descriptions of five new species (Hymenoptera). Esakia, (14) : 93-111.

3-067. YOSHIDA, Nariaki and HIRASHIMA, Yoshihiro 1979. Systematic studies on Proctotrupoid and Chalcidoid parasites of gall midges injurious to Pinus and Cryptomeria in Japan and Korea (Hymenoptera). Esakia, (14) : 113-133.

3-068. HIRASHIMA, Yoshihiro, TADAUCHI, Osamu and SUDA, Hirohisa 1979. New or little 
known bees of Japan (Hymenoptera, Apoidea). I. Supplementary note on two Andrena species. Esakia, (14) : 135-143.

3-069. HIRASHIMA, Yoshihiro 1979. Discovery of the second species of Prosopisteroides of New Guinea (Hymenoptera, Colletidae). Esakia, (14): 145-148.

3-070. 平嶋義宏・多田内修 (HIRASHIMA, Yoshihiro and TADAUCHI, Osamu) 1979. 新渴県の七メ八 ナバチ. [A list of the genus Andrena (Hymenoptera, Andrenidae) of Niigata Prefecture] 越 佐昆会報, (50)：1-8. (In Japanese with English summary)

3-071. MAKIHARA, Hiroshi 1979. Tribe Clytini of Okinawa Prefecture (Coleoptera :Cerambycidae). Esakia, (14) : 149-173.

3-072. HTRASHIMA, Yoshihiro and TADAUCHI, Osamu 1979. New or little known bees of Japan (Hymenoptera, Apoidea). II. Bees of Colletes and Epeolus of Niigata Prefecture with description of a new Colletes species. J.Fac. Agr., Kyushu Univ., 24 : 113-123.

3-073. YAMAGISHI, Kenzou 1980. A new species of Trichacoides from Japan (Hymenoptera, Platygastridae). Kontŷu, $48: 95-99$.

3-074. YAMAGISHI, Kenzou 1980. A new record of Encyrtoscelio apterus (Szelényi) from Korea (Hymenoptera, Scelionidae). Nat. \& Life, Taegu, $10: 17-22$.

3-075. HIRASHIMA, Yoshihiro 1980. A synopsis of the bee genus Palaeorhiza Perkins (Hymenoptera, Colletidae) of New Guinea. Part III. Subgenera Trachyrhiza, Paraheterorhiza, Hadrorhiza. J.Fac. Agr., Kyushu Univ., 25 : 99-117.

3-076. MORIMOTO, Katsura 1980. The family Anthribidae of Japan (Coleoptera). Part 3. Esakia, (15) : 11-47.

3-077. MAKIHARA, Hiroshi 1980. Cerambycidae of the Danjo Islands, with descriptions of two new species and six new subspecies (Coleoptera). Esakia, (15) : 49-73.

3-078. OKUMA, Chiyoko 1980. Notes on a spider, Tetragnatha laqueata L. Koch, 1871 of the Bonin Islands, Japan (Araneae: Tetragnathidae): Esakia, (15): 75-78.

3-079. YAMAMOTO, Masaru 1980. Discovery of the Nearctic genus Chasmatonotus Loew (Diptera, Chironomidae) from Japan, with descriptions of three new speceis. Esakia, (15) : 79-96.

3-080. ÔHARA, Kenji 1980. The genus Platycheirus Lepeletier and Serville, 1828 (Diptera, Syrphidae) of Japan, with descriptions of three new species. Esakia, (15) : 97-142.

3-081. KIFUNE, Teiji and HIRASHIMA, Yoshihiro 1980. Records of the Strepsiptera of Sri Lanka in the collection of the Smithsonian Institution, with descriptions of seven new species (Notulae Strepsipterologicae-VI). Esakia, (15) : 143-159.

3-082. YAMAGISHI, Kenzou 1980. Platygastrid parasites of willow gall midges in Japan (Hymenoptera, Proctotrupoidea). Esakia, (15) : 161-175.

3-083. HIRASHIMA, Yoshihiro 1981. A synopsis of the bee genus Palaeorhiza Perkins (Hymenoptera, Colletidae) of New Guinea. Part IV. Subgenus Cheesmania. Kontya 49 : 27-36.

3-084. NAOMI, Shun-Ichiro 1981. On the genus Anisolinus Sharp (Coleoptera, Staphylinidae), with description of a new species. Konty $\hat{u}, 49: 109-115$. 
3-085. HIRASHIMA, Yoshihiro and YAMAGISHI, Kenzou 1981. Redescriptions of the types of some Japanese Scelionidae preserved in the United States National Museum (Hymenoptera, Proctotrupoidea). J.Fac. Agr., Kyushu Univ., 25 : 153-159.

3-086. MIURA, Tadashi, HIRASHIMA, Yoshihiro, CHÔJÔ, Michitaka and CHU, Yau-i 1981. Egg and nymphal parasites of rice leafhoppers and planthoppers. A result of field studies in Taiwan in 1979 (Part 1). Esakia, (16) : 39-50.

3-087. MORIMOTO, Katsura 1981. Curculionidae and Rhynchophoridae (Coleoptera) of the Ogasawara Islands. Part 1. Otiorhynchinae and Cryptorhynchinae (I). J. Fac. Agr., Kyushu Univ., 25 : 175-199, 2 pls.

3-088. MORIMOTO, Katsura 1981. Functional morphology and phylogeny of the superfamily Curculionoidea (Coleoptera). Part 1. The mouth parts. Akitu, 34:1-10.

3-089. 大熊千代子・岸本良一 (OKUMA, Chiyoko and KISIMOTO, Ryoiti) 1981. 東シナ海々上で捕獲 された飛行グモ. [Air borne spiders collected over the East China Sea] 応動昆, 25:296-298. (In Japanese with English summary)

3-090. HIRASHIMA, Yoshihiro 1982. Comments on the bee fauna of Japan (Hymenoptera : Apoidea). Ent. Gen., $8:$ 89-97.

3-091. OGATA, Kazuo 1982. Taxonomic study of the ant genus Pheidole Westwood of Japan, with a description of a new species (Hymenoptera, Formicidae). Kontyâ, 50: 189-197.

3-092a. YAMAGISHI, Kenzou 1982. Contribution to the knowledge of the Platygastridae of Japan (Hymenoptera, Proctotrupoidea). Kontyâ, 50 : 88-94.

3-092b. HIRASHIMA, Yoshihiro 1981. A synopsis of the bee genus Palaeorhiza Perkins (Hymenoptera, Colletidae) of New Guinea. Part V. Subgenus Cnemidorhiza. Esakia, (17) : l-48.

3-093. HIRASHIMA, Yoshihiro and NAGASE, Hirohiko 1981. New or little known bees of Japan (Hymenoptera, Apoidea). III. Pasites esakii, a genus and species new to Japan. Esakia, (17) : 4952.

3-094. MORIMOTO, Katsura 1981. The family Anthribidae of Japan (Coleoptera). Part 4. Esakia, (17) : 53-107.

3-095. MORIMOTO, Katsura 1981. On some Japanese Curculioninae (Coleoptera : Curculionidae). Esakia, (17) : 109-130.

3-096. OKUMA, Chiyoko 1981. A new species of the genus Tetragnatha (Araneae: Tetragnathidae) from the Bonin Islands, Japan. Esakia, (17) : 141-147.

3-097. MIZUKUBO, Takayuki 1981. A revision of the genus Blattella (Blattaria: Blattellidae) of Japan. I. Terminology of the male genitalia and description of a new species from Okinawa Island. Esakia, (17) : 149-159.

3-098. TADAUCHI, Osamu 1981. Taxonomic working system by computer (SAC) with application to Japanese Andrenid bees. Esakia, (17) : 161-182.

3-099. HAYASHI, Masao and MAKIHARA, Hiroshi 1981. The Cerambycidae (Coleoptera) of Nepal collected by the Kyushu University Scientific Expedition. Esakia, (17) : 183-200.

3-100. HIRASHIMA, Yoshihiro 1982. A synopsis of the bee genus Palaeorhiza Perkins (Hymenopter- 
a, Colletidae) of New Guinea. Part VI. Subgenus Zarhiopalea.Kontya, 50: 57-66.

3-101. SAHAD, Kazi Abdus 1982. Biology and morphology of Gonatocerus sp. (Hymenoptera, Mymaridae), an egg parasitoid of the green rice leafhopper, Nephotettix cincticeps Uhler (Homoptera, Deltocephalidae). I. Biology. Kontyâ, 50: 246-260.

3-102. YAMAMOTO, Masaru 1981. Two new species of the genus Stenochironomus from Japan (Diptera : Chironomidae). Bull. Kitakyushu Mus. Nat. Hist., 3: 41-51.

3-103. HIRASHIMA, Yoshihiro 1982. A synopsis of the bee genus Palaeorhiza Perkins (Hymenoptera, Colletidae) of New Guinea. Part VII. Subgenus Cercorhiza.J.Fac.Agr., Kyushu Univ., 26 : 87-109.

3-104. MAETÔ, Kaoru 1982. The genus Homolobus Foerster of Japan (Hymenoptera, Braconidae). I. Subgenus Homolobus. Kontyâ, 50 : 314-323.

3-105. MAETÔ, Kaoru 1982. The genus Homolobus Foerster of Japan (Hymenoptera, Braconidae). II. Subgenera Chartolobus, Apatia, Phylacter and Oulophus. Kontyâ, 50 : 425-433.

3-106. MAETÔ, Kaoru 1982. A new species of the genus Homolobus (Hymenoptera, Braconidae) from New Guinea. Kontyû, 50: 527-530.

3-107. NAOMI, Shun-lchiro 1982. Revision of the subtribe Xanthopygina (Coleoptera, Staphylinidae) of Japan. I. Kontyâ, $50:$ 125-133.

3-108. SAHAD, Kazi Abdus 1982. Biology and morphology of Gonatocerus sp. (Hymenoptera, Mymaridae), an egg parasitoid of the green rice leafhopper, Nephotettix cincticeps Uhler (Homoptera, Deltocephalidae). II. Morphology. Kontya, 50 : 467-476.

3-109. TADAUCHI, Osamu 1982. Character correlations of hairs in the Japanese Andrenid bees. Kontyâ, 50: 411-424.

3-110. TADAUCHI, Osamu 1982. A numerical taxonomic study of the genus Andrena (Hymenoptera, Andrenidae) of Japan. J.Fac.Agr., Kyushu Univ., 26 : 169-191.

3-111, MORIMOTO, Katsura 1982. On the subfamilies Magdalinae and Carciliinae of Japan (Coleoptera : Curculionidae). Spec. Iss. M em. Retir.Emer.Prof.M.Châjô, 153-164.

3-112. MORIMOTO, Katsura 1982. On some Japanese Brentidae (Coleoptera). Ent. Rev. Japan, 37 : 31-36, 1 pl.

3-113. Missing number.

3-114, NAOMI, Shun-Ichiro 1983. Revision of the subtribe Xanthopygina (Coleoptera, Staphylinidae) of Japan II. Kontyâ, 51 : 47-55.

3-115. NAOMI, Shun-Ichiro 1982. Description of a new Subgenus Paramichrotus of the genus Amichrotus Sharp from Taiwan (Coleoptera : Staphylinidae). Trans. Shikoku Ent. Soc., 16 : 37-39.

3-116. HIRASHIMA, Yoshihiro and LIEFTINCK, M. A. 1982. Systematic studies on the genus Palaeorhiza of New Guinea collected by the Third Archbold Expedition (I) (Hymenoptera, Colletidae). Esakia, (19) : 1-50.

3-117, MORIMOTO, Katsura 1982. The family Curculionidae of Japan. I. Subfamily Hylobinae. 
Esakia, (19) : 51-121.

3-118, TADAUCHI, Osamu 1982. Factor analysis of integumental sculptures in the Japanese Andrenid bees. Esakia, (19) : 135-150.

3-119. KIFUNE, Teiji, HIRASHIMA, Yoshihiro and MAETA, Yasuo 1982. Four new species of the genus Halictoxenos Pierce from Japan (Strepsiptera, Stylopidae) (Studies on the Japanese Strepsiptera VI). Esakia, (19) : 151-160.

3-120. SAKAGAMI, Shôichi F., HIRASHIMA, Yoshihiro, MAETA, Yasuo and MATSUMURA, Takeshi 1982. Bionomic notes on the social halictine bee Lasioglossum affine (Hymenoptera, Halictidae). Esakia, (19) : 161-176.

3-121. SHIOKAWA, Makoto and HIRASHIMA, Yoshihiro 1982. Synopsis of the flavipes-group of the bee genus Ceratina of eastern Asia (Hymenoptera, Anthophoridae). Esakia, (19) : 177-184.

3-122, TOGASHI, Ichiji and HIRASHIMA, Yoshihiro 1982. Wood-wasps or horn-tails of the Amami-Oshima Island, with description of a new species (Hymenoptera : Siricoidea). Esakia, (19) : 185-189.

3-123, SAHAD, Kazi Abdus 1982. Descriptions of new species of Gonatocerus Nees and Anagrus Haliday from Japan (Hymenoptera, Mymaridae). Esakia, (19) : 191-204.

3-124. 江田信豊 (KÔDA, Nobutoyo) 1982. 日本産ミドリシジミ類 5 種の雄の活動性とそれに対する照度 の影響について. [Observation on the male activity of five Japanese species of Zephyrus hairstreaks, with special reference to the influence of the light intensity (Lepidoptera, Lycaenidae)] 蝶と蛾, $33: 29-39$. (In Japanese with English summary)

3-125. MAETÔ, Kaoru 1983. Discovery of two genera, Sarops Nixon and Protodacnusa Griffiths, from Japan (Hymenoptera, Braconidae). Kontyû, 51: 247-253.

3-126, GOTÔ, Tadao 1983. A new phorid fly of the genus Crinophleba from Japan (Diptera, Phoridae). Kontyâ, 51: 376-383.

3-127, YOSHIYASU, Yutaka and ÔHARA, Kenji 1982. A new aphidophagous species of a phycitine genus Cryptoblabes from Japan (Lepidoptera, Pyralidae). Tyô to Ga, 33: 51-60.

3-128, TADAUCHI, Osamu 1983. Summarization of taxonomic information in the Japanese

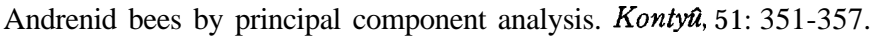

3-129, MAETÔ, Kaoru 1983. A systematic study on the genus Polemochartus Schulz (Hymenoptera,

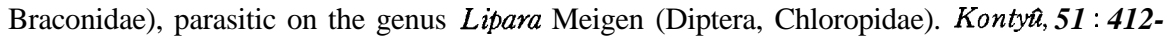
425.

3-130. NAOMI, Shun-Ichiro 1983. Revision of the subtrible Xanthopygina (Coleoptera, Staph-

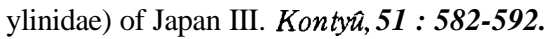

3-131, MORIMOTO, Katsura 1983. The family Curculionidae of Japan. II. Viticiinae, subfam. nov. Esakia, (20) : 55-62.

3-132, MORIMOTO, Katsura 1983. The family Curculionidae of Japan. III. Subfamily Anoplinae. Esakia, (20) : 63-68.

3-133. OKUMA, Chiyoko 1983. New synonymies and new records of some cosmopolitan species of the genus Tetragnathu (Araneae: Tetragnathidae). Esakia, (20) : 69-80. 
3- 134, TADAUCHI, Osamu and HIRASHIMA, Yoshihiro 1983. New or little known bees of Japan (Hymenoptera, Apoidea) IV. Supplements to Andrena (Simandrena). Esakia, (20) : 81-92.

3-135, HIRASHIMA, Yoshihiro and LIEFTINCK, M. A. 1983. Systematic studies on the genus Palaeorhiza of $\mathrm{New}$ Guinea collected by the Third Archbold Expedition (II) (Hymenoptera, Colletidae). Esakia, (20): 93-129.

3-136. OGATA, Kazuo 1983. The ant genus Cerapachys F. Smith of Japan, with description of a new species (Hymenoptera, Formicidae). Esakia, (20) : 131-137.

3-137, GOTÔ, Tadao and TAKENO, Kôichi 1983. Discovery of the genus Aenigmatias Meinert from Japan, with a redescription of A. dorni (Enderlein) (Diptera, Phoridae). Esakia, (20) : 139-148.

3-138, GOTÔ, Tadao and TAKENO, Kôichi 1983. A new Triphleba species with bifurcate antennae from Japan (Diptera, Phoridae). Esakia, (20) : 149-156.

3-139. KIFUNE, Teiji and HIRASHIMA, Yoshihiro 1983. Records of the Strepsiptera from Australia and Sri Lanka in the collection of the Smithsonian Institution, with descriptions of four new species (Notulae Strepsipterologicae-XI). Esakia, (20) : 157-165.

3-140. KIFUNE, Teiji and HIRASHIMA, Yoshihiro 1983. A new species of the genus Halictophagus from Thailand (Strepsiptera : Halictophagidae) (Notulae Strepsipterologicae-XII). Esakia, (20) : 167-169.

3-141, GOTÔ, Tadao 1984. Two new species of the genus Trophithauma Schmitz from Japan (Diptera, Phoridae). Bull. Kitakyushu Mus. Nat. Hist., 5: 75-84.

3-142. GOTÔ, Tadao 1984. Systematic study of the genus Phora Latreille from Japan (Diptera, Phoridae). I. Description of a new species, with discussion on the terminology of the male

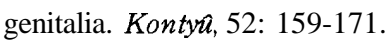

3-143, HIRASHIMA, Yoshihiro and TADAUCHI, Osamu 1984. Two new species of Prosopisteroides from Papua New Guinea (Hymenoptera, Colletidae, Hylaeus). Esakia, (21) : 59-65.

3-144. TADAUCHI, Osamu and HIRASHIMA, Yoshihiro 1984. New or little known bees of Japan (Hymenptera, Apoidea) V. Supplements to Andrena (Hoplandrena). Kontyâ, 52 : 278-285.

3-145, NAOMI, Shun-Ichiro 1984. Studies on the genus Phytolinus Sharp (Coleoptera, Staphylinidae)

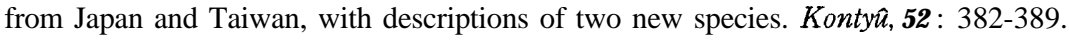

3-146. SAHAD, Kazi Abdus and HIRASHIMA, Yoshihiro 1984. Taxonomic studies on the genera Gonatocerus Nees and Anagrus Haliday of Japan and adjacent regions, with notes on their biology (Hymenoptera, Mymaridae). Bull. Inst. Trop.Agr., Kyushu Univ., 7 : I-78.

3-147, ÔHARA, Kenji 1984. Mature larva and puparium of Dideoidescoquilletti van der Goot (Diptera, Syrphidae). Kontyâ, 52 : 445-447.

3-148, NAOMI, Shun-Ichiro 1984. Studies on the genus Oligota Mannerheim (Coleoptera, Staphylinidae) from Japan. I. On the species-group of 0. yasumatsui Kistner, with description of a new subspecies. Konty $\hat{a}, 52:$ 516-521.

3-149, ÔHARA, Kenji 1984. Taxonomic note on Syrphus nipponensis van der Goot (Diptera, Syrphidae). Kontyû, 52: 533-536.

3-150. GOTÔ, Tadao 1985. Systematic study of the genus Phora Latreille from Japan (Diptera, 
Phoridae). II. Descriptions of four new species. Konty $\hat{\imath}, 53: 1-11$.

3-151, RYU, Joon and HIRASHIMA, Yoshihiro 1984. Taxonomic studies on the genus Trissolcus Ashmead of Japan and Korea (Hymenoptera, Scelionidae). J. Fac. Agr., Kyushu Univ., 29 : 35-58.

3-152. CHANTARASA-ARD, Sujin, HIRASHIMA, Yoshihiro and MIURA, Tadashi 1984. Ecological studies on Anagrus incarnatus Haliday (Hymenoptera : Mymaridae), an egg parasitoid of the rice planthoppers. I. Functional response to host density and mutual interference. J. Fac. Agr., Kyushu Univ., 29 : 59-66.

3-153, CHANTARASA-ARD, Sujin, HIRASHIMA, Yoshihiro and MIURA, Tadashi 1984. Ecological studies on Anagrus incarnatus Haliday (Hymenoptera : Mymaridae), an egg parasitoid of the rice planthoppers. II. Spatial distribution of parasitism and host eggs in the paddy field. $J$. Fac. Agr., Kyushu Univ., 29: 67-76.

3-154, CHANTARASA-ARD, Sujin, HIRASHIMA, Yoshihiro and HIRAO, Jutaro 1984. Host range and host suitability of Anagrus incarnatus Haliday (Hymenoptera : Mymaridae), an egg parasitoid of delphacid planthoppers. Appl. Ent. Zool., $19: 491-497$.

3-155, MORIMOTO, Katsura 1984. The family Curculionidae of Japan. IV. Subfamily Rhynchaeninae. Esakia, (22):5-76.

3-156. KIFUNE, Teiji and HIRASHIMA, Yoshihiro 1984. Synopsis of the genus Halictophagus (Strepsiptera: Halictophagidae) of Japan, with description of a new species (Studies on the Japanese Strepsiptera VIII). Esakia, (22) : 77-85.

3-15'7. OKUMA, Chiyoko 1984. Notes on the African species of Tetragnatha (Araneae :Tetragnathidae). Esakia, (22) : 87-93

3-158, ÔHARA, Kenji 1984. Supplementary notes on the genus Platycheirus of Japan (Diptera, Syrphidae). Esakia, (22) : 95-102.

3-159, TAMASAWA, Shusaburo and HIRASHIMA, Yoshihiro 1984. A new species of Andrena from Japan (Hymenoptera, Andrenidae). Esakia, (22): 103-105.

3-160. TADAUCHI, Osamu and HIRASHIMA, Yoshihiro 1984. Synopsis of Andrena (Euandrena) of Japan (Hymenoptera, Andrenidae). Esakia, (22) : 107-113.

3-161, HIRASHIMA, Yoshihiro and ROBERTS, Hywel 1984. Bees of the genus Palaeorhiza Perkins (Hymenoptera, Colletidae) in the National Forest Insect Collection of the Forest Research Station, Bulolo, Papua New Guinea (I). Esakia, (22) : 115-128.

3-162. SAHAD, Kazi Abdus 1984. Biology of Anagrus optabilis (Perkins) (Hymenoptera, Mymaridae), an egg parasitoid of delphacid planthoppers. Esakziz, (22) : 129-144.

3-163, CHANTARASA-ARD, Sujin, HIRASHIMA, Yoshihiro and MIURA, Tadashi 1984. Effects of temperature and food on the development and reproduction of Anagrus incarnatus Haliday (Hymenoptera : Mymaridae), an egg parasitoid of the rice planthoppers. Esakia, (22) : 145158.

3-164. CHANTARASA-ARD, Sujin 1984. Preliminary study on the overwintering of Anagrus incarnatus Haliday (Hymenoptera : Mymaridae), an egg parasitoid of the rice planthoppers. Esukia, (22) : 159-162. 
3-165, KANAZAWA, Itaru 1984. A revision of the genus Stenolechia Meyrick from Japan (Lepidoptera, Gelechiidae). Tyô to Ga, 35 : 93-120.

3-166, ÔHARA, Kenji 1985. The larvae and puparia of four Japanese species of the genus Volucella Geoffroy (Diptera, Syrphidae), I. Kontyâ, $53:$ 204-212.

3-167, ÔHARA, Kenji 1985. The larvae and puparia of four Japanese species of the genus Volucella Geoffroy (Diptera, Syrphidae), II. Kontyâ, 53 : 379-386.

3-168, GOTÔ, Tadao 1985. Systematic study of the genus Phora 'Latreille from Japan (Diptera, Phoridae) III. Kontyû, $53: 547-560$.

3- 169. KONISHI, Kazuhiko 1985. A revision of the subgenus Parabates Foerster of the genus Ne telia Gray from Japan (Hymenoptera, Ichneumonidae). Kontyâ, 53 : 616-624.

3-170. HIROWATARI, Toshiya 1986. Study on the genus Jamides Hübner (Lepidoptera, Lycaenidae). I. Descriptions of the female genitalia of sixteen species from the Malay Peninsula. Tyô to Ga, 36: 113-132.

3-171. MORIMOTO, Katsura and MIYAKAWA, Sumiaki 1985. Weevil fauna of the Izu Islands, Japan (Coleoptera). Mushi, 50 : 19-85.

3-172, GOTÔ, Tadao 1985. Systematic study of the genus Phora Latreille from Japan (Diptera, Phoridae) IV. Kontyâ, 53 : 658-670.

3-173. RYU, Joon and HIRASHIMA, Yoshihiro 1985. Taxonomic studies on the genus Telenomus Haliday of Japan and Korea (Hymenoptera, Scelionidae) Part I. J. Fac. Agr., Kyushu Univ., $30: 9-30$.

3-174, RYU, Joon and HIRASHIMA, Yoshihiro 1985. Taxonomic studies on the genus Telenomus Haliday of Japan and Korea (Hymenoptera, Scelionidae) Part II. J. Fac. Agr., Kyushu Univ., 30: 31-51.

3-175. TADAUCHI, Osamu 1985. Synopsis of Andrena (Micrandrena) of Japan (Hymenoptera, Andrenidae) Part I. J.Fac. Agr., Kyushu Univ., 30 : 59-76.

3-176, TADAUCHI, Osamu 1985. Synopsis of Andrena (Micrandrena) of Japan (Hymenoptera, Andrenidae) Part II. J.Fac. Agr., Kyushu Univ., 30 : 77-94.

3-177. GOTÔ, Tadao 1986. Systematic study of the genus Phora Latreille from Japan (Diptera, Phoridae) V. Kontyâ, 54 : 128-142.

3-178. MORIMOTO, Katsura 1986. The family Curculionidae of Japan. V. Tribe Camptorhinini. Ent. Pap. pres. Kurosawa, Tokyo, pp. 321-334.

3-179. NAOMI, Shun-Ichiro 1986. Taxonomic study on the genus Velleius Mannerheim of Japan, with description of a new species (Coleoptera : Staphylinidae). Trans. Shikoku Ent. Soc., 17 : 239-246.

3-180. NAOMI, Shun-Ichiro 1986. A taxonomic study on the subfamily Megalopininae (Coleoptera, Oxyporidae) of Japan, with descriptions of two new species. Kontyâ, $54: 344-352$.

3-181. NAOMI, Shun-Ichiro 1985. The phylogeny and higher classification of the Staphylinidae and their allied groups (Coleoptera, Staphylinoidea). Esakia, (23) : l-27. 
3-182, TADAUCHI, Osamu 1985. The effect of using various character subsets on numerical taxonomy in the Japanese Andrenid bees. Esakia, (23) : 29-40.

3-183, OKUMA, Chiyoko 1985. A new species of the genus Tetragnatha from Africa (Araneae: Tetragnathidae). Esakia, (23): 41-44.

3-184. KIFUNE, Teiji and HIRASHIMA, Yoshihiro 1985. Nine new species of the genus Stylops (Strepsiptera : Stylopidae) parasitic on the genus Andrena (Hymenoptera : Andrenidae) of Japan (Studies on the Japanese Strepsiptera X). Esakia, (23) : 45-57.

3-185, MORIMOTO, Katsura 1985. Supplement to the check-list of the family Rhychophoridae (Coleoptera) of Japan, with descriptions of a new genus and four new species. Esakia, (23) : 6776.

3-186, GOTÔ, Tadao 1985. Megaselia (Aphiochaeta) araneivora sp. nov., an egg predator of the orbweb spider Argiope aemura (Walckenaer) in Japan (Diptera, Phoridae). Esakia, (23) : 77-84.

3-187, GOTÔ, Tadao 1985. A review of the Oriental genus Rhopica, with description of a new species from Papua New Guinea (Diptera, Phoridae). Esakia, (23) : 85-92.

3-188. YAMAMOTO, Masaru 1985. Two new species of the genus Chasmatonotus from Japan (Diptera, Chironomidae). Esakia, (23) : 93-98.

3-189, ÔHARA, Kenji 1985. Observations on the oviposition behaviour of Metasyrphus confrater (Diptera, Syrphidae) and the defensive behaviour of soldiers of Pseudoregma bambucicola (Homoptera, Pemphigidae). Esakziz, (23) : 99-105.

3-190. ÔHARA, Kenji 1985. Observations on the prey-predator relationship between Pseudoregma bambucicola (Homoptera, Pemphigidae) and Metasyrphus confrater (Diptera, Syrphidae), with special reference to the behaviour of the aphid soldiers. Esakia, (23) : 107-110.

3-191, PARK, Ki-Nam, MIURA, Tadashi and HIRASHIMA, Yoshihiro 1985. Outbreaks history and present status of the pine needle gall midge in Korea. Esakia, (23): 115-118.

3-192. LEE, Buom Young, MIURA, Tadashi and HIRASHIMA, Yoshihiro 1985. Survivorship and other factors relating to population fluctuations of the pine needle gall midge, Thecodiplosis japonensis (Diptera, Cecidomyiidae). Esakziz, (23):119-130.

3-193, JEON, Mun-Jang, LEE, Buom-Young, KO, Je-Ho, MIURA, Tadashi and HIRASHIMA, Yoshihiro 1985. Ecology of Platygastermatsutama and Inostemmu seoulis (Hymenoptera : Platygastridae), egg-larval parasites of the pine needle gall midge, Thecodiplosis japonensis (Diptera, Cecidomyiidae). Esakia, (23) : 131-143.

3-194. LEE, Buom-Yong, KO, Je-Ho, CHOI, Byung-Hoe, JEON, Mun-Jang, MIURA, Tadashi and HIRASHIMA, Yoshihiro 1985. Utilization of proctotrupoid wasps in Korea for control of the pine needle gall midge, Thecodiplosis japonensis (Diptera, Cecidomyiidae). Esakia, (23) : 145150.

3-195. KO, Je-Ho and MORIMOTO, Katsura 1985. Loss of tree vigor and role of boring insects in red pine stands heavily infested by the pine needle gall midge in Korea. Esakia, (23) : 151-158.

3-196. OGATA, Kazuo, HIRASHIMA, Yoshihiro, MIURA, Tadashi, MAETA, Yasuo, YANO, Kôji and KO, Je-Ho 1985. Ants collected in pine forests infested by the pine needle gall midge in Korea (Hymenoptera, Formicidae). Esakia, (23) : 159-163. 
3-197, YAMAMOTO, Masaru 1986. Study of the Japanese Chironomus inhabiting high acidic water (Diptera, Chironomidae) I. Kontyâ, 54: 324-332 .

3-198, KONISHI, Kazuhiko 1986. A revision of the subgenus Apatagium Enderlein of the genus Netelia Gray from Japan (Hymenoptera, Ichneumonidae). Kontyâ, 54: 261-270.

3-199, SAWADA, Yoshihisa and MORIMOTO, Katsura 1985. A revision of the genus Euops Schoenherr (Coleoptera : Attelabidae) from Japan, Korea and Taiwan. J.Fac. Agr., Kyushu Univ., 30: 175-195.

3-200. HIRASHIMA, Yoshihiro and ROBERTS, Hywel 1986. Discovery of the bee genus Pharohylaeus Michener from Papua New Guinea, with description of a new species (Hymenoptera, Colletidae). Esakia, (24) : 63-66.

3-201. GOTÔ, Tadao 1986. Hypogeophora macrothrix gen. et sp. nov., a myrmecophilous phorid fly (Diptera, Phoridae) associated with Pheidole fervida Fr. Smith (Hymenoptera, Formicidae) in Japan. Kontya, 54 : 303-308.

3-202. MORIMOTO, Katsura 1986. Notes on some Japanese Anthribidae (Coleoptera). Pap. Ent. pres. Nakane, Tokyo, 273-277.

3-203. HIROWATARI, Toshiya 1986. Morphology and taxonomic importance of the female genitalia of the genus Nacaduba Moore (Lepidoptera, Lycaenidae). Tyô to Ga, 37:51-60.

3-204. YATA, Osamu, ABE, Masaki and NAKAI, Mamoru 1986. Relationship between androconial scale and the male wing odour in Pieris melete Ménétriès (Lepidoptera, Pieridae). Sieboldia, $\mathbf{5}$ : 131-136.

3-205. 沢田佳久 ・森本桂 (SAWADA, Yoshihisa and MORIMOTO, Katsura) 1986. ルリオトシブミ属 Euops から新たに発見された胞子顀と胞子の摇籃への伝搬方法 (甲虫目: オトシブミ科). [The mycetangia and the mode of the fungus transmission in the weevil genus Euops (Coleoptera : Attelabidae)) 九大農学芸誌, $40: 197-205$. (In Japanese with English summary)

3-206. ABE, Yoshihisa 1986. Taxonomic status of the Andricus mukaigawae complex and its speciation with geographic parthenogenesis (Hymenoptera: Cynipidae). Appl. Ent. Zool., 21: 436447.

3-207. KONISHI, Kazuhiko 1986. A new subgenus and species of the genus Netelia (Hymenoptera, Ichneumonidae) from New Guinea. Kontya $54: 415-419$.

3-208. NAOMI, Shun-Ichiro and TERAYAMA, Mamoru 1986. Discovery of the subtribe Termitozyrina (Coleoptera, Staphylinidae, Aleocharinae) in Japan, with description of a new genus and species. Kontyû, $54: 504-508$.

3-209. NAOMI, Shun-Ichiro 1987. Discovery of the subfamily Hypocyptinae (Coleoptera : Staphylinidae) from Japan, with description of a new species. Trans. Shikoku Ent. Soc., 18 : 273-275.

3-210. NOMURA, Shahei 1986. Descriptions of two new myrmecophilous species of the family Pselaphidae (Coleoptera) from Japan. Kontyâ, 54: 498-503.

3-211. SAWADA, Yoshihisa and LEE, Chan-Young 1986. On a new leaf-rolling weevil related to Deporausbetulae (Coleoptera, Attelabidae). Kontya, 54: 672-680.

3-212, TADAUCHI, Osamu, HIRASHIMA, Yoshihiro and MATSUMURA, Takeshi 1987. Synopsis 
of Andrena (Andrena) of Japan (Hymenoptera, Andrenidae) Part I. J.Fac.Agr., Kyushu univ., 31: 11-35.

3-213, TADAUCHI, Osamu, HIRASHIMA, Yoshihiro and MATSUMURA, Takeshi 1987. Synopsis of Andrena (Andrena) of Japan (Hymenoptera, Andrenidae) Part II. J. Fac.Agr., Kyushu univ., $31: 37-54$.

3-214, NAOMI, Shun-Ichiro and TERAYAMA, Mamoru 1986. Taxonomic study of the subfamily Trichopseniinae (Coleoptera, Staphylinidae) of Japan, with descriptions of three new species. Kontyâ, 54: 697-705.

3-215, NAOMI, Shun-Ichiro 1986. Redescription and systematic notes of Aspidobactrus claviger Sharp (Coleoptera, Staphylinidae). Proc. Japn.Soc. syst. Zool., (34) : 46-52.

3-216, LEE, Chan-Young and MORIMOTO, Katsura 1987. Larvae of the weevil family Anthribidae of Japan (Coleoptera). J.Fac.Agr., Kyushu U niv., 31: 71-86.

3-217, NAOMI, Shun-Ichiro 1986. Taxonomic study on the subfamily Osoriinae (Coleoptera, Oxytelidae) from Japan, I. Elytra, $14:$ 33-42.

3-218, NAOMI, Shun-Ichiro 1987. Taxonomic study on the subfamily Osoriinae (Coleoptera, Oxytelidae) from Japan, II. Elytra, $15: 12-18$.

3-219. MIZUKUBO, Takayuki and HIRASHIMA, Yoshihiro 1987. Homology of male genital sclerites in cockroaches (Blattaria) by means of analysis of their association patterns. J. Fac. Agr., Kyushu Univ., 31 : 247-277, 10 pls.

3-220. OKUMA, Chiyoko 1987. A revision of the Australasian species of the genus Tetragnatha (Araneae, Tetragnathidae). Esakia, (25) : 37-96.

3-221, OGATA, Kazuo 1987. A generic synopsis of the poneroid complex of the family Formicidae in Japan (Hymenoptera). Part I. Subfamilies Ponerinae and Cerapachyinae. Esakia, (25) : 97132.

3-222. TADAUCHI, Osamu and HIRASHIMA, Yoshihiro 1987. Descriptions of two new species and one unrecorded female of the genus Andrena from Japan (Hymenoptera, Andrenidae). Esakia, (25) : 133-139.

3-223, MORIMOTO, Katsura and LEE, Chan-Young 1987. On the homology of the thoracic and abdominal areas of the weevil larvae as based on a study of the muscles (Coleoptera : Curculionoidea). Esakiu, (25) : 141-148.

3-224, YAMAMOTO, Masaru 1987. Note on the genus Chaetolabis Townes status nov., with a redescription of C. macani (Freeman) (Diptera, Chironomidae). Esakia, (25) : 149-154.

3-225, KIFUNE, Teiji and HIRASHIMA, Yoshihiro 1987. Three new species of the genus Paraxenos (Strepsiptera : Stylopidae) parasitic on Bembix (Hymenoptera : Sphecidae) of Sri Lanka and Australia in the collection of the Smithsonian Institution (Notulae Strepsipterologicae-XVII). Esakia, (25) : 155-160.

3-226, NAOMI, Shun-Ichiro 1987. Comparative morphology of the Staphylinidae and the allied groups (Coleoptera, Staphylinoidea). I. Introduction, head sutures, eyes and ocelli. Kontyâ, 55 : 450-458.

3-227. NAOMI, Shun-Ichiro 1987. Comparative morphology of the Staphylinidae and the allied 
groups (Coleoptera, Staphylinoidea). II. Cranial structure and tentorium. Kontyâ, 55 : 666-675.

3-228. NAOMI, Shun-Ichiro 1988. Comparative morphology of the Staphylinidae and the allied

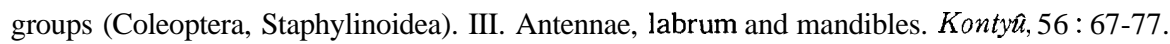

3-229. NAOMI, Shun-Ichiro 1988. Comparative morphology of the Staphylinidae and the allied groups (Coleoptera, Staphylinoidea). IV. Maxillae and labium. Konty $\hat{u}, 56: 241-250$.

3-230. ROBERTS, Hywel and MORIMOTO, Katsura 1987. New Platypodidae (Coleoptera) from the mountain forests of Papua New Guinea. Esakia, (25): 161-181.

3-231, MORIMOTO, Katsura 1987. The family Curculionidae of Japan. VI. Tribe Mechistocerini Part 1 (Insecta, Coleoptera). J. Fac. Agr., Kyushu Univ., 31 : 321-343.

3-232. MORIMOTO, Katsura 1987. The family Curculionidae of Japan. VI. Tribe Mechistocerini Part 2 (Insecta, Coleoptera). J. Fac. Agr., Kyushu Univ., 31 : 345-364.

3-233. HIROWATARI, Toshiya 1987. Systematic position of Pepliphorus cyanea (Cramer) (Lepidoptera, Lycaenidae). Tyô to $G a, 38: 31-37$.

3-234. SAWADA, Yoshihisa 1987. A revision of the tribe Deporaini of Japan (Coleoptera, Attelabidae). I. Descriptions of taxa. 1. Genera Apoderites, Eusproda,Chokkirius and Paradeporaus. Kontŷu, 55 : 654-665.

3-235. OKUMA, Chiyoko and DIPPENAAR-SCHOEMAN, A. S. 1988. Tetragnatha (Araneae : Tetragnathidae) in the collection of the Plant Protection Research Institute, Pretoria with a description of a new species. Phytophylatica, Pretoria, (20) : 219-232.

3-236. ABE, Yoshihisa 1988. Trophobiosis between the gall wasp, Andricus symbio ticus, and the gall-attending ant, Lasius niger. Appl. Ent. Zool., $23: 41-44$.

3-237. TERAYAMA, Mamoru and OGATA, Kazuo 1988. Two new species of the ant genus Probolomyrmex (Hymenoptera, Formicidae) from Japan. Kontyû, $56: 590-594$.

3-238, NAOMI, Shun-Ichiro 1988. Studies on the subfamily Steninae from Japan I. New or little known species of the genus Dianous Leach (Coleoptera, Oxyporidae). Trans. Shikoku Ent. Soc.,19(1-2): 47-57.

3-239. NAOMI, Shun-Ichiro 1988. Studies on the subfamily Steninae (Coleoptera : Oxyporidae) from Japan II. Subgenus Hemistenus of the genus Stems Latreille. Proc. Japn. Soc. syst. Zool., (37): $27-33$.

3-240. NAOMI, Shun-Ichiro 1988. Studies on the subfamily Steninae (Coleoptera, Oxyporidae) from Japan III. New or little known species of the subgenus Nestus of the genus Stenus Latreille. Proc. Japn. Soc. Syst. Zool. (38) : 43-50.

3-241. NAOMI, Shun-Ichiro 1988. Studies on the subfamily Steninae from Japan IV. New or little known species of the subgenus Stems s. str. of the genus Stenus Latreille (Coleoptera, Oxyporidae). Trans. Shikoku Ent. Soc., 19(1-2): 55-62.

3-242. Missing number.

3-243. YASUNAGA, Tomohide 1988. A new species of the genus Creontiades (Heteroptera, Miridae) from Japan, with a note on C. tricolor. Kontŷu, 56 : 475-479. 
3-244. NAOMI, Shun-Ichiro. Studies on the subfamily Steninae (Coleoptera, Oxyporidae) from Japan V. Subgenus Tesnus of the genus Stenus Latreille, with a key to the species of the subgenera Tesnus and Nestus. Proc. Japn.Soc. Syst.Zool. (in press)

3-245, NAOMI, Shun-Ichiro 1988. Studies on the subfamily Steninae (Coleoptera, Oxyporidae) from Japan VI. Subgenus Parastenus of the genus Stenus, Part 1. Elytra, 16: 33-40.

3-246. NAOMI, Shun-Ichiro 1987. Studies on the subfamily Steninae (Coleoptera, Oxyporidae) from Japan, VII. Subgenus Parastenus of the genus Stenus Lateille (Part 2). Akitu, (87) : 1-9.

3-247. NAOMI, Shun-Ichiro 1988. Studies on the subfamily Steninae (Coleoptera, Oxyporidae) from Japan, VIII. Subgenus Parastenus of the genus Stews Latreille, Part 3. Elytra, 16: 65-71.

3-248. SAWADA, Yoshihisa 1988. A revision of the tribe Deporaini (Coleoptera, Attelabidae) of Japan. II. Systematics. 1. Redefinitions of the tribe and genera. Kontya, 56 : 553-564.

3-249. HIRASHIMA, Yoshihiro 1988. Bees of the genus Palaeorhiza Perkins (Hymenoptera, Colletidae) of Papua New Guinea collected by the Kyushu University Expedition, I. Esakia, (26) : $5-19$.

3-250. HIRASHIMA, Yoshihiro, ABE, Masaki and YOSHIDA, Mutsuhiro 1988. Note on the life cycles of Inurois kyushuensis and Arichanna melanaria (Lepidoptera, Geometridae), pests of Rhododendron kiusianum in the Kuzyu Mountains. Esakia, (26) : 21-24, 1 pl.

3-251. MORIMOTO, Katsura 1988. The family Curculionidae of Japan. VII. Genera Colobodes Schoenherr, Deretiosus Pascoe and Deretiosopsis nov. (Insecta, Coleoptera). Esakia, (26) : 39-70.

3-252. OKUMA, Chiyoko 1988. Five new species of Tetragnatha from Asia (Araneae :Tetragnathidae). Esakia, (26) : 71-77.

3-253, MORAKOTE, Rut 1988. Four new species of Nephrocerus Zetterstedt (Diptera: Pipunculidae) from Japan. Esakia, (26) : 79-90.

3-254. ABE, Masaki 1988. A biosystematic study of the genus Athalia Leach of Japan (Hymenoptera: Tenthredinidae). Esakia, (26): 91-131.

3-255. MIYAMOTO, Shôiti and YASUNAGA, Tomohide 1988. A new genus and species of the Miridae from Japan (Hemiptera, Heteroptera). Esakia, (26) : 133-138.

3-256, OKUMA, Chiyoko 1988. A revision of the genus Tetragnatha Latreille (Araneae, Tetragnathidae) of Asia, Part I. J.Fac. Agr., Kyushu Univ., 32 : 165-181.

3-257, OKUMA, Chiyoko 1988. A revision of the genus Tetragnatha Latreille (Araneae, Tetragnathidae) of Asia, Part II. J.Fac. Agr., Kyushu U niv., 32 : 183-213.

3-258, GOTÔ, Tadao. Immature stages of the fungsgnats, Bolitophila japonica (Okada) and Mycetophila lineola Meigen (Diptera, Mycetophilidae). Jpn._I. Ent., Tokyo. (in press)

3-259. NOMURA, Shahei 1988. A revision of the subtribe Acetaliina (Coleoptera, Pselaphidae) from Japan, Part I. Kontya, 56: 251-260.

3-260. NOMURA, Shahei 1988. A revision of the subtribe Acetaliina (Coleoptera, Pselaphidae) from Japan, Part II. Kontyâ, 56 : 515-521.

3-261. NOMURA, Shahei 1988. A revision of the subtribe Acetaliina (Coleoptera, Pselaphidae) from 
Japan, Part III. Kontyâ, 56(4) : 739-751.

3-262, NAOMI, Shun-Ichiro 1988. Comparative morphology of the Staphylinidae and the allied groups (Coleoptera, Staphylinoidea). V. Cervix and prothorax. Kontŷu, $56: 506-513$.

3-263. NAOMI, Shun-Ichiro 1988. Comparative morphology of the Staphylinidae and the allied groups (Coleoptera, Staphylinoidea). VI. Mesothorax and metathorax. Kontyä, 56(4) : 727-738.

3-264. NAOMI, Shun-Ichiro. Comparative morphology of the Staphylinidae and the allied groups (Coleoptera, Staphylinoidea). VII. Metendosternite and wings. Jpn.J.Ent., Tokyo. (in press)

3-265. NAOMI, Shun-Ichiro. Comparative morphology of the Staphylinidae and the allied groups (Coleoptera, Staphylinoidea). VIII. Thoracic legs. Jpn. J. Ent., Tokyo. (in press)

3-266. NAOMI, Shun-Ichiro. Comparative morphology of the Staphylinidae and the allied groups (Coleoptera, Staphylinoidea). IX. General structure, lateral plates, stigmata and 1st to 7th segments of abdomen. Jpn. J. Ent., Tokyo. (in press)

3-267. NAOMI, Shun-Ichiro. Comparative morphology of the Staphylinidae and the allied groups (Coleoptera, Staphylinoidea). X. Eighth to 10th segments of abdomen. Jpn. J.Ent., Tokyo. (in press)

3-268, NAOMI, Shun-Ichiro. Comparative morphology of the Staphylinidae and the allied groups (Coleoptera, Staphylinoidea). XI. Abdominal glands, male genitalia and female spermatheca. Jpn. J. Ent., Tokyo. (in press)

3-269. LEE, Chan-Young and MORIMOTO, Katsura 1988. Larvae of the weevil family Attelabidae of Japan. Part 1. Subfamily Attelabinae (Insecta: Coleoptera). J. Fac. Agr., Kyushu Univ., 32 : 215-237.

3-270. LEE, Chan-Young and MORIMOTO, Katsura 1988. Larvae of the weevil family Attelabidae of Japan. Part 2. Subfamily Rhynchitinae (Insecta: Coleoptera). J. Fac. Agr., Kyushu Univ., $32: 239-254$.

3-271, KÔDA, Nobutoyo 1987. A generic classification of the subfamily Arctiinae of the Palaearctic and Oriental regions based on the male and female genitalia (Lepidoptera, Arctiidae) Part I. Tyô to Ga, 38 : 153-237.

3-272, ABE, Yoshihisa 1988. Two host races in Andricus mukaigawae (Mukaigawa) (Hymenoptera: Cynipidae). Appl.Ent. Zool., $23:$ 381-387.

3-273. KÔDA, Nobutoyo 1988. A generic classification of the subfamily Arctiinae of the Palaearctic and Oriental regions based on the male and female genitalia (Lepidoptera, Arctiidae) Part II. Tyô to $G a, 39: 1-79$.

3-274, MIYAMOTO, Syôiti and YASUNAGA, Tomohide. Two new species of the Miridae from Japan and Taiwan (Heteroptera). Jpn. J. Ent., Tokyo. (in press)

3-275, PARSONS, Michael and HIROWATARI, Toshiya 1988. A new species of Callictita BethuneBaker (Lepidoptera, Lycaenidae) from Irian Jaya, Indonesia. 1. Tyô to Ga, 39(4) : 259-262.

3-276, OKUMA, Chiyoko 1988. Redescription of the Hawaiian spiders of Tetragnatha described by Simon (Araneae, Tetragnathidae). J. Fac. Agr., Kyushu Univ., 33 : 77-86.

3-277. NOMURA, Shâhei. Description of a new species of Apharinodes (Coleoptera, Pselaphidae) 
from Okinawa Island, Japan. Jpn. J.Ent., Tokyo. (in press)

3-278. NOMURA, Shûhei. Taxonomic study on the genus Paracyathiger from Japan (Pselaphidae, Coleoptera). Jpn. J.Ent., Tokyo. (in press)

3-279. TADAUCHI, Osamu and HIRASHIMA, Yoshihiro 1988. Synopsis of Andrena (Stenomelissa) with a new species from Japan (Hymenoptera, Andrenidae). J.Fac. Agr., Kyushu Univ., 33 : $67-76$.

3-280. LEE, Chan-Young and MORIMOTO, Katsura 1988. Larvae of the weevil family Curculionidae of Japan. Part 1. Key to genera and short-nosed group (Insecta; Coleoptera). $J$. Fac. Agr., Kyushu Univ., 33: 109-130.

3-281. LEE, Chan-Young and MORIMOTO, Katsura 1988. Larvae of the weevil family Curculionidae of Japan. Part 2. Hyperinae to Cioninae (Insecta: Coleoptera). J.Fac. Agr., Kyushu Univ., 33: 131-152.

3-282, NAOMI, Shun-Ichiro 1988. Studies on the subfamily Steninae (Coleoptera, Oxyporidae) from Japan, IX. Subgenus Hypostenus of the genus Stenus Latreille, Part 1. Elytra, 16 (2) : 73-84.

3-283. NAOMI, Shun-Ichiro. Studies on the subfamily Steninae (Coleoptera, Oxyporidae) from Japan, X. Subgenus Hypostenus of the genus Stenus Latreille (Part 2). Akitsu. (in press)

3-284. NAOMI, Shun-Ichiro. Studies on the subfamily Steninae (Coleoptera, Oxyporidae) from Japan, XI. Subgenus Hypostenus of the genus Stenus Latreille (Part 3). Akitsu. (in press)

3-285. NAOMI, Shun-Ichiro. Studies on the subfamily Steninae (Coleoptera, Oxyporidae) from Japan, XII. Subgenus Hypostenus of the genus Stenus Latreille, Part 4. Elytra. (in press)

3-286. NAOMI, Shun-Ichiro. Studies on the subfamily Steninae (Coleoptera, Oxyporidae) from Japan, XIII. Subgenus Hypostenus of the genus Stenus Latreille, Part 5. Jpn. J.Ent., Tokyo. (in press)

3-287, NAOMI, Shun-Ichiro. Studies on the subfamily Steninae (Coleoptera, Oxyporidae) from Japan, XIV. Subgenus Hypostenus of the genus Stenus Latreille, Part 6. Jpn. J. Ent., Tokyo. (in press)

3-288, NAOMI, Shun-Ichiro. Studies on the subfamily Steninae (Coleoptera, Oxyporidae) from Japan, XV. Subgenus Hypostenus of the genus Stenus Latreille, Part 7. Jpn. J.Ent., Tokyo. (in press)

3-289. HIRASHIMA, Yoshihiro 1989. A synopsis of the bee genus Palaeorhiza Perkins (Hymenoptera, Colletidae) of New Guinea. Part VIII. Subgenus Callorhiza. Esakia, (28) : 1-9, $1 \mathrm{pl}$.

3-290. KIFUNE, Teiji and HIRASHIMA, Yoshihiro 1989. Taxonomic studies on the Strepsiptera in the collection of the Bishop Museum (Notulae Strepsipterologicae-XX). Esakia, (28) : 11-48.

3-291, RYU, Joon and HIRASHIMA, Yoshihiro. 1989. Taxonomic studies on the genera Aporophlebus, Eumicrosoma and Platytelenomus of Japan and Korea (Hymenoptera, Scelionidae, Telenominae). Esakiu, (28) : 49-62.

3-292. HIRASHIMA, Yoshihiro, ABE, Masaki, TADAUCHI, Osamu, KONISHI, Kazuhiko and MAETÔ, Kaoru 1989. The hymenopterous parasitoids of the diamondback moth, Plutella xylostella (Lepidoptera, Yponomeutidae) in Japan. Esakia, (28) : 63-73. 
3-293, YASUNAGA, Tomohide. A revision of the genus Adel phocoris Reuter (Heteroptera, Miridae) from Japan. Part I. Jpn.J.Ent., Tokyo. (in press)

3-294. YASUNAGA, Tomohide. A revision of the genus Adel phocoris Reuter (Heteroptera, Miridae) from Japan. Part II. Jpn.J.Ent., Tokyo. (in press)

3-295, 平嶋義宏 • 野原啓吾・三浦正 (HIRASHIMA, Yoshihiro, NOHARA, Keigo and MIURA, Tadashi) 1989. コナガの生物的防除に関する研究， 1. 天敵の種類とその利用. [Studies on the biological control of the diamondback moth, Plutella xylostella (Linnaeus), 1. Insect natural enemies and their utilization] 九大農学芸誌, 投稿中

3-296. 平嶋義宏・三浦一芸・三浦正・城耕治 (HIRASHIMA, Yoshihiro, MIURA, Kazuki, MIURA, Tadashi and SHIRO, Koji) 1989.コ3ガの生物的防除に関する研究, 2 .卵寄生蜂 2 種の発育と温 度の関係. [Studies on the biological control of the diamondback moth, Plutellaxylostella (Linnaeus), 2. Effect of temperature on the development of the egg-parasitoids, Ttichogramma chilonis and Trichogrammu osttiniae] 九大農学芸誌, 投稿中

3-297. 平鴆義宏 ·三浦一芸・三浦正 (HIRASHIMA, Yoshihiro, MIURA, Kazuki and MIURA, Tadashi) 1989. コナガの生物的防除に関する研究, 3. 卵寄生蜂 2 種の增殖に利用する寄生卵の発育阻害に つ৬て. [Studies on the biological control of the diamondback moth, Plutella xylostella (Linnaeus), 3. On the growth obstruction of host eggs utilized for mass culture of Trichogrammu chilonis and Trichogramma ostriniae] 九大農学芸誌,投稿中

3-298. 平沜義宏 •三浦一芸・三浦正・長谷川徹 (HIRASHIMA, Yoshihiro, MIURA, Kazuki, MIURA, Tadashi and HASEGAWA, Toru) 1989. コナガの生物的防除に関する研究, 4. 卵寄生蜂 2 種の 增殖能力に及济す温度の影響. [Studies on the biological control of the diamondback moth, Plutella xylostella (Linnaeus), 4. Effect of temperature on the population of the egg-parasitoids, Trichogramma chilonis and Trichogramma osttiniae] 九大農学芸誌,投稿中

3-299. 平嶋義宏 •三浦一芸 •三浦正 • 松田賢 (HIRASHIMA, Yoshihiro, MIURA, Kazuki, MIURA, Tadashi and MATSUDA, Satoshi) 1989. コナガの生物的防除に関する研究, 5. 卵寄生蜂 2種の 寄主密度に対する反応. [Studies on the biological control of the diamondback moth, Plutella xylostella (Linnaeus), 5. Functional responses of the egg-parasitoids, Trichogramma chilonis and Trichogramma ostriniae, to host densities] 九大農学芸誌投稿中

3-300。平鳴義宏·三浦一芸・三浦正 (HIRASHIMA, Yoshihiro, MIURA, Kazuki and MIURA, Tadashi) 1989. コナガの生物的防除に関する研究, 6. コナガの防除に利用する 2 種の卵寄生蜂の大量增殖 法. [Studies on the biological control of the diamondback moth, Plutella xylostella (Linnaeus), 6. New techniques for mass culture of the egg-parasitoids, Trichogrammu chilonis and Trichogramma ostriniae] 九大農学芸誌, 投稿中

3-301. MORAKOTE, Rut and HIRASHIMA, Yoshihiro. A systematic study of the Japanese Pipunculidae (Diptera). Part I. Introduction to the family and the genus Verrallia Mik. $J$. Fac. Agr., Kyushu Univ. (in press)

3-302. MORAKOTE, Rut and HIRASHIMA, Yoshihiro. A systematic study of the Japanese Pipunculidae (Diptera). Part II. The genus Chalarus Walker. J.Fac. Agr., Kyushu Univ. (in press)

3-303. MORAKOTE, Rut and HIRASHIMA, Yoshihiro. A systematic study of the Japanese Pipunculidae (Diptera). Part III. The genus Cephalops Fallen. J.Fac.Agr., Kyushu Univ. (in press) 
3-304. MORAKOTE, Rut and HIRASHIMA, Yoshihiro. A systematic study of the Japanese Pipunculidae (Diptera). Part IV. The genus Pipunculus Latreille. J.Fac. Agr., Kyushu Univ. (in press)

3-305. MORAKOTE, Rut, HIRASHIMA, Yoshihiro and YANO, Kôji. A systematic study of the Japanese Pipunculidae (Diptera). Part V. The genus Eudorylas Aczél. J.Fac.Agr., Kyushu Univ. (in press)

3-306. MORAKOTE, Rut, HIRASHIMA, Yoshihiro and YANO, Kôji. A systematic study of the Japanese Pipunculidae (Diptera). Part VI. The genera Dorylomorpha Aczél and Tomosvaryella Aczél. J.Fac. Agr., Kyushu Univ. (in press)

\section{Appendix}

The following papers were published in ESAKIA as results of studies supported by "Grants-in-Aid for Overseas Scientific Survey" from the Japan Ministry of Education, Science and Culture to Kyushu University (Principal Investigator : Prof. Y. Hirashima). These papers were not classified in the Subject Index or Author Index.

A-1, CHU, Yau-i and HIRASHIMA, Yoshihiro 1981. Survey of Taiwanese literature on the natural enemies of rice leafhoppers and planthoppers. Esakia, (16) : 33-37.

A-2. HIRASHIMA, Yoshihiro 1981. Field studies on the biological control of leafhoppers and planthoppers (Hemiptera : Homoptera) injurious to rice plants in South-East Asia. An account for the year 1979. Esakia, (16) : 1-4.

A-3. HIRASHIMA, Yoshihiro 1984. Ecological studies on insect species diversities and productivities in the highland agricultural ecosystems of Papua New Guinea. A progress report for the year 1982. Esakia, (21) : 1-4.

A-4. HIRASHIMA, Yoshihiro 1986. Biological studies on insect species diversities and productivities in the highland agricultural ecosystems of Papua New Guinea : A progress report for the year 1984. Esakia, (24) : 1-4.

A-5. ISMAY, J. W. 1986. New species of Dicraeus (Diptera, Chloropidae) from New Guinea and New Ireland. Esakia, (21) : 5-17.

A-6. ISMAY, J. W. 1986. New Psilacrum from the Old World (Diptera, Chloropidae). Esakia, (24) : 19-35.

A-7. KIMOTO, Shinsaku, ISMAY J. W. and SAMUELSON, G. A. 1984. Distribution of Chrysomelid pests associated with certain agricultural plants in Papua New Guinea (Coleoptera). Esakia, (21) : 49-57.

A-8. KURAHASHI, Hiromu 1986. Blow flies of medical importance in New Guinea, Bismarck Archipelago and Bougainville Island (Diptera : Calliphoridae) Part I. Genera Calliphora, Tainanina, Polleniopsis and Melinda. Esakia, (24) : 5-18.

A-9. ROBERTS, Hywel 1986. New Platypodidae (Coleoptera) from the rain forests of Papua New Guinea. Esakia, (24) : 37-58. 
A-10. SAMUELSON, G. A. 1984. Plant associated Alticinae from the Bismarck Range, Papua New Guinea (Coleoptera : Chrysomelidae). Esakia, (21) : 31-47.

A-11. SHINONAGA, Satoshi and KANO, Rokuro 1984. Eleven new Helina-species collected on wet stones along mountain streams in Papua New Guinea (Diptera : Muscidae). Esakia, (21) : 1929.

A-12. TOGASHI, Ichiji 1986. A new species of the genus Neostromboceros Rohwer (Hymenoptera, Tenthredinidae) from New Britain, Papua New Guinea. Esakia, (24) : 50-61.

A-13. YANO, Kôji 1979. Faunal and biological studies on the insects of paddy fields in Asia. Part II.. Illustrated key to the Thai species of Pipunculidae (Diptera). Esakia, (13) : 45-54.

A-14. YANO, Kôji, MIYAMOTO, Syôiti and GABRIEL, B. P. 1981. Fauna1 and biological studies on the insects of paddy fields in Asia. IV. Aquatic and semiaquatic Heteroptera from the Philippines. Esakia, (16) : 5-32. 


\section{SUBJECT INDEX TO SERIES 3}

EVOLUTION AND PHYLOGENY

Coleoptera 088, 181

\section{SYSTEMATICS}

Araneae

Tetragnathidae 038, 050, 064, 078, 096, $133,157,183,220,235,252,256,257$, 276

Blattaria

Blattellidae 097

Coleoptera

Anthribidae 052, 060, 076, 094, 202

Apionidae 171

Attelabidae 171, 199, 211, 234, 248

Brentidae 061, 112, 171

Cerambycidae 030, 035, 036, 053, 071, 077, 099

Curculionidae 049, 087, 095, 111, 117, $131,132,155,171,178,231,232,251$

Oxyporidae 180, 238, 239, 240, 241, 244, $245,246,247,282,283,284,285,286$, 287, 288

Oxyteridae 217, 218

Platypodidae 230

Pselaphidae 210, 259, 260, 261, 277, 278

Rhynchophoridae 056, 087, 171, 185

Staphylinidae 084, 107, 114, 115, 130, $145,148,179,208,209,214,215$

Staphylinoidea 181

Diptera

Chironomidae 048, 079, 102, 188, 197, 224

Chloropidae 003

Phoridae 126, 137, 138, 141, 142, 150, $168,172,177,186,187,201$

Pipunculidae 253, 301, 302, 303, 304, 305, 306

Sciomyzidae 041

Syrphidae 080, 149, 158

Hemiptera

Cicadidae 011, 013, 019, 022, 024, 031a, 031b, 037

Miridae 243, 255, 274, 293, 294

Hymenoptera

Andrenidae 009, 023, 068, 134, 144,159,
$160,175,176,212,213,222,279$

Anthophoridae 093, 121

Apoidea 072, 090

Braconidae 042, 104, 105, 106, 125, 129

Chalcidoidea 066, 067

Colletidae 027, 028, 034, 047, 054, 069, $075,083,092 \mathrm{~b}, 100,103,116,135,143$, 161, 200, 249, 289

Cynipidae 004, 206

Embolemidae 029

Formicidae 091, 136, 221, 237

Halictidae 055

Ichneumonidae 169, 198, 207

Megachilidae 007, 008, 010

Mymaridae 123, 146

Platygastridae 067, 073, 082, 092a

Scelionidae 065, 074, 085, 151, 173, 174, 291

Siricidae 122

Tenthredinidae 254

Xiphidriidae 122

Lepidoptera

Arctiidae 271, 273

Gelechiidae 165

Lycaenidae 170, 233, 275

Pyralidae 014, 026, 127

Mecoptera

Panorpidae 062

Strepsiptera

Corioxenidae 063, 139, 290

Elenchidae 021, 044, 290

Halictophagidae 044, 045,081, 139, 140, 156, 290

Mengenillidae 081, 139

Myrmecolacidae 012, 063, 081, 139, 290

Stylopidae 081, 119, 184, 225

\section{BIOSYSTEMATICS}

Hymenoptera

Tenthredinidae 254

MORPHOMETRICS

Hymenoptera 109, 118

NUMERICAL TAXONOMY

Hymenoptera 
Andrenidae 018, 039, 040, 098, 110, 128, 182

\section{ZOOGEOGRAPHY \\ Hemiptera \\ Cicadidae 022 \\ Local fauna \\ Hong Kong 032 \\ Japan}

Danjo-Gunto 077

Izu Islands 171

Japan proper 090

Nansei Islands (incl. the Ryukyus)

Coleoptera 035, 071

Hemiptera 011, 013, 019, 022

Niigata Prefecture

Coleoptera 059

Hymenoptera 070, 072

Ogasawara $(=$ Bonin $)$ Islands 087

Korea 196

Nepal 031a,031b, 099

New Guinea

Coleoptera 230

Hymenoptera 116, 135, 161, 249

Philippines 032

Sri Lanka 081

Thailand 020, 032

\section{MORPHOLOGY}

Eggs and immature stages

Coleoptera 211, 216, 223, 265, 269, 270, 280,281

Diptera 003, 048, 147, 166, 167, 197, 258

Hemiptera 025

Hymenoptera 043, 108, 162

Lepidoptera 017, 127

\section{Adults}

Blattaria 097, 219

Coleoptera 088, 205, 226, 227, 228, 229, $262,263,264,266,267,268$

Diptera 142

Hymenoptera 043,108

Lepidoptera 051, 170, 203

\section{BEHAVIOR, BIOLOGY AND ECOLOGY}

Habits and life-histories

Araneae 078

Hymenoptera
Colletidae 027, 103, 116

Cynipidae 004

Halictidae 120

Megachilidae 010

Mymaridae 101, 146, 152, 153, 162, 163, 164, 193

Trichogrammatidae 043

Lepidoptera

Geometridae 017, 250

Association with fungus and plant $\mathbf{0 0 2 , 0 1 7}$

Digital communication 001

Dispersal 006

Fungus transmission 205

Leaf-rolling habits 211

Light intensity 124

Mimicry 057

Nesting habits 027, 120

Oviposition 189

Predatory habits 015, 127, 186, 190

Speciation 206, 272

Symbiosis 201, 236

\section{PHYSIOLOGY}

Androconial scales 204

ENVIRONMENTAL ENTOMOLOGY

Pests of Rhododendron 017, 250

APPLIED ENTOMOLOGY

Diamondback moth 292, 295, 296, 297, 298, 299, 300

Food insects 057

Natural enemies and biological control 044, 057, 058, 066, 067, 082, 086, 154, 292, 295, 296, 297, 298, 299, 300

Paddy field insects and spiders 005, 016, 032, 033, 041, 046

Pine needle gall midge 191, 192, 193, 194, 195, 196

Trapping 016, 020, 089 


\section{AUTHOR INDEX TO SERIES 3}

\section{A}

ABE, Masaki (阿部正喜) 204, 250, 254292

ABE, Yoshihisa (阿部芳久) 206, 236, 272

AIZAWA，Keio（鮎沢啓夫） 057

ASAHINA, Syoziro（朝比奈正二郎） 032

\section{C}

CHANTARASA-ARD, Sujin 152, 153, 154, 163, 164

CHIKUNI，Yasunosuke (千国安之輔) 050

CHOI, Byung-Hoe (崔炳會) 194

CHU, Yau-i (朱耀沂) 086

CHÛ fO, Michitaka (中條道崇) 002, 017, 086

$$
\mathrm{D}
$$

DIPPENAAR-SCHOEMAN, A S. 235

\section{G}

GOTÔ, Tadao（後藤忠男） 126, 137, 138, 141, 142， $150,168,172,177,186,187,201,258$

$\mathrm{H}$

HANEDA，Yoshito (羽田義任) 009

HASEGAWA, Toru (長谷川徹) 298

HAYASHI, Masami (林正美) 011,013，019,022， 024, 025, 031, 037

HAYASHI, Masao (林匡夫) 099

HIRAO，Jutaro（平尾重太郎） 154

HIRASHIMA, Yoshihiro (平嶋義宏) 001, 007, 008, 009, 010, 012, 017, 021, 023, 027, 028, 029, 034, 044, 045, 047, 054, 055, 057, 058, 063, 065, 067, 068, 069, 070, 072, 075, 081, 083, 085, 086, 090, 092b, 093, 100,103, 116, 119, 120,121, 122 , $134,135,139,140,143,144,146,151,152,153$, $154,156,159,160,161,163,173,174,184,191$, $192,193,194,196,200,212,213,219,222,225$, $249,250,279,289,290,291,292,295,296,297$, 298, 299, 300, 301, 302, 303, 304, 305, 306

HIROWATARI，Toshiya (広渡俊哉) 170, 203， 233, 275

HOKYO, Nobuhiko (法橋信彦) 046

\section{$\mathbf{J}$}

JEON, Mun-Jang (全文章) 193, 194

$\mathrm{K}$

KAMIJO, Kazuaki (上条一昭) 066 KANAZAWA，Itaru（金沢至） 165

KANMIYA，Kenkichi (上宮健吉) 003

KIFUNE，Teiji（木船悌嗣）012，021，044，045, 063, 081, 119, 139, 140, 156, 184, 225, 290

KISIMOTO, Ryoiti (岸本良一) 089

KO, Je-Ho (高済鎬) 193, 194, 195, 196

KÔDA, Nobutoyo (江田信豊) 124, 271, 273

KONISHI，Kazuhiko (小西和彦) 169, 198, 207, 292

\section{L}

LEE, Buom Young (李範英) $192,193,194$

LEE, Chan-Young (李倸鏞) 211, 216, 223, 269, 270, 280, 281

LEE, Lawrence H. Y. 020, 032

LEE, Moon Hong (李文洪) 046

LIEFTINCK, M. A. 116, 135

\section{$\mathrm{M}$}

MAETA, Yasuo（前田泰生） 007, 119, 120, 196

MAETÔ, Kaoru (前藤薰) $\quad 104,105,106,125,129$, 292

MAKIHARA，Hiroshi（楨原寛）002，030，035， 036, 053, 062, 071, 077, 099

MATSUDA，Satoshi（松田賢） 299

MATSUMURA，Takeshi(松村雄) 120,212, 213

MIURA，Kazuki (三浦一芸) 296，297，298，299， 300

MIURA, Tadashi (三浦正) 020，032，057，058, 086, 152, 153, 163, 191, 192, 193, 194, 196, 295 , 296, 297, 298, 299, 300

MIYAKAWA，Sumiaki (宮川澄昭) 171

MIYAMOTO, Shôiti(宮本正一) 062, 255, 274

MIYAZAKI, Minoru (宮崎稔) 065

MIZUKUBO, Takayuki (水久保隆之) 097, 219

MORAKOTE, Rut 253, 301, 302, 303, 304, 305, 306 
MORIMOTO, Katsura（森本桂） 049, 052, 056, 059, 060, 061, 076, 087, 088, 094, 095, 111, 112 , $117,131,132,155,171,178,185,195,199,202$, $205,216,223,230,231,232,251,269,270,280$, 281

\section{$\mathrm{N}$}

NAGASE，Hirohiko（長瀬博彦） 093

NAKAI，Mamoru (中井衛) 204

NAKAO，Shun-ichi (中尾舜一) 032

NAOMI，Shun-Ichiro（直海俊一郎） 084, 107, 114, $115,130,145,148,179,180,181,208,209,214$, $215,217,218,226,227,228,229,238,239,240$, $241,244,245,246,247,262,263,264,265,266$, $267,268,282,283,284,285,286,287,288$

NAVAVICHIT, Suchada 015

NILPANIT, Pinit 015

NOHARA, Keigo (野原啓吾) 020, 295

NOMURA，Shahei (野村周平) 210, 259, 260, 261, 277,278

0

OGATA，Kazuo（緒方一夫）091，136，196，221， 237

ÔHARA, Kenji (大原賢二) 080，127，147，149， $158,166,167,189,190$

OKUMA Chiyoko（大熊千代子) 005，016，033， 038, 046, 050, 064, 078, 089, 096, 133, 157, 183, $220,235,252,256,257,276$

\section{$\mathrm{P}$}

PANGGA, Guillermo A. 032

PARK，Ki-Nam (朴基南) 191

PARSONS, Michael 275

\section{$\mathrm{R}$}

RESMA, Paulino W. 020

ROBERTS, Hywel 161, 200, 230

RYU，Joon (柳駿) $151,173,174,291$

\section{S}

SAHAD, Kazi Abdus 101, 108, 123, 146, 162

SAKAGAMI, Shôichi F. (坂上昭一) 120
SAWADA, Yoshihisa（沢田佳久）199，205，211, 234,248

SHIOKAWA，Makoto（塩川信） 121

SIRO，Koji（城耕治） 296

SUDA，Hirohisa（須田博久) 068

SUZUKI，Yoshito（鈴木芳人） 006

\section{T}

TADAUCHI，Osamu（多田内修） 018, 023，039, 040, 068, 070, 072, 098, 109, 110, 118, 128, 134, $143,144,160,175,176,182,212,213,222,279$, 292

TAKAGI，Masami（高木正見） 006

TAKENO, Kôichi (竹野功一) 002，137，138

TAKETANI, Akihiko (竹谷昭彦) 004

TAMASAWA，Shusaburo（玉沢脩三郎） 159

TERAYAMA, Mamoru (寺山守) 208, 214, 237

TOGASHI, Ichiji（富樫一次） 122

U

UEDA，Kyoichiro（上田恭一郎） 051

$$
\mathrm{V}
$$

VUNGSILABUTR, Preecha 043

\section{$\mathrm{W}$}

WONGSIRI, Tanongchit 005, 015, 020, 032, 057, 058

\section{$\mathrm{Y}$}

YAMAGISHI, Kenzou（山岸健三） 029, 073, 074, 082, 085, 092a

YAMAMOTO, Masaru (山本優) 048, 079, 102, $188,197,224$

YAMANAKA，Masahiro（山中正博） 006

YANO，Kôji (矢野宏二) 015, 017, 020, 032, 041, 196, 305, 306

YASUMATSU，Keizô(安松京三) 004, 015，066

YASUNAGA，Tomohide (安永智秀) 243, 255, 274, 293, 294

YATA，Osamu（矢田脩） 204

YONEDA，Yutaka（米田豊） 042

YOSHIDA，Mutsuhiro（吉田睦浩） 250

YOSHIDA，Nariaki (吉田成章) 067

YOSHIYASU, Yutaka (吉安裕) 014, 026, 127 